MARCIN PIGULAK

Instytut Filmu, Mediów i Sztuk Audiowizualnych Uniwersytet im. Adama Mickiewicza w Poznaniu
Images

vol. XXIX/no. 38

Poznań 2021

ISSN 1731-45OX

\title{
Gry pamięci. \\ Valiant Hearts: The Great War $i$ My Memory of Us w perspektywie kultury historycznej
}

\begin{abstract}
Aвstract. Pigulak Marcin, Gry pamięci. Valiant Hearts: The Great War $i$ My Memory of Us $w$ perspektywie kultury historycznej [Games of Memory. Valiant Hearts: The Great War and My Memory of Us in the perspective of historical culture]. "Images" vol. XXIX, no. 38. Poznań 2021. Adam Mickiewicz University Press. Pp. 143-160. ISSN 1731-450X. DOI 10.14746/i.2021.38.09.
\end{abstract}

The paper aims to outline how video games Valiant Hearts: The Great War (Ubisoft Montpellier, 2014) and My Memory of Us (Juggler Games, 2018) use narrative and ludic structures to create commemorative stories about the First World War and the Second World War. The author refer to the concept of historical culture (among others, in Jörn Rüsen's interpretation) and examine the connections between the two video games focusing on the issue of designers' intentions (digital games as examples of the commemoration of the past), the genre similarity (2D platform games), the intermedial convergence and the press reception. He discusses the strategy of the cultural agreement between designers and users, analyzes historical narratives as a part of the gameplay, examines relations between the individual and collective's perspective and characterizes immersion's mechanisms which reinforce players' identification with the victims of both wars.

KEYwORDs: Valiant Hearts: The Great War, My Memory of Us, historical games, historical culture, collective memory, game studies

Gry wideo aktywnie partycypują w kształtowaniu kulturowych horyzontów współczesności. Rozpoczęły swoje popkulturowe życie wraz z sukcesem automatów arkadowych na początku lat 70., w przeciągu niespełna połowy wieku stały się nie tylko czołowym produktem globalnej rozrywki, ale również jednym z najbardziej wpływowych mediów swoich czasów. Potwierdzenie takiej oceny na gruncie game studies mogą stanowić założenia Daniela Murry’ego i Garry’ego Crawforda, którzy w monografii Video Games as Culture. Considering the Role and Importance of Video Games in Contemporary Society sformułowali cztery kluczowe twierdzenia opisujące znaczenie gier wideo w kontekście przemian społeczno-kulturowych:

1. Gry wideo to niewątpliwie współczesna rzeczywistość;

2. Gry wideo ucieleśniają niektóre z najważniejszych aspektów współczesnego społeczeństwa;

3. Gry wideo są uznanymi produktami kultury;

4. Istnieje rosnąca i konsolidująca się kultura gier wideo[1].

[1] D. Muriel, G. Crawford, Video Games as Culture. Considering the Role and Importance of Video Games in Contemporary Society, London - New York

\section{Wprowadzenie}

2018, s. 3; tłum. własne (jeśli nie zaznaczono inaczej, wszystkie tłumaczenia pochodzą od autora). 
Przyjmując wymienione twierdzenia za podstawę uznania kulturotwórczej roli elektronicznej rozrywki, zamierzam na przykładzie dwóch zorientowanych historycznie gier - Valiant Hearts: The Great War oraz My Memory of Us - podjąć rozważania na temat sposobu, w jaki medium to kształtuje i ugruntowuje kulturowy dyskurs o przeszłości (odpowiednio: o I i II wojnie światowej). Chociaż istnieje szereg definicji próbujących zawęzić pojęcie „gier historycznych” do ich faktograficznego wymiaru[2], z uwagi na potrzeby niniejszego tekstu - poruszającego między innymi zagadnienia pamięci zbiorowej i kultury historycznej - odwołuję się do szerokiej definicji, traktującej ten gatunek jako „sposób reprezentowania przeszłości, odnoszenia się do dyskusji na jej temat lub stymulowania praktyk z nią związanych" [3]. Tak przyjęta strategia jest tym zasadniejsza, że obecna w nich przeszłość inspiruje badaczy do refleksji opartej na szeregu interpretacyjnych ścieżek leżących na styku historiografii, historiozofii oraz pisarstwa o pamięci[4].

Małgorzata Pakier, poszukując wspólnego mianownika dla znaczących teorii z zakresu kultury historycznej, definiuje ją jako „całokształt sposobów odnoszenia się do przeszłości charakterystyczny dla pewnej grupy, wyodrębnionej ze względy na narodowość, język, religię, pochodzenie społeczne czy inne cechy kulturowe. Składają się nań zarówno wszelkie teksty kultury przedstawiające wizje przeszłości, jak i kulturowe praktyki określające sposoby przywoływania przeszłości w kontekście społecznym" [5]. Podążając za typologią badaczki, za kluczowe pojęcia kultury historycznej uznaję aktorów pamięci (między innymi deweloperów i społeczność graczy), media, dzięki którym pamięć się kształtuje i rozprzestrzenia (rozumiane również jako nośniki: komputer, smartfon lub konsola), reprezentacje kulturowe (omawiane tytuły), a także aktywne procesy ich recepcji (recenzje prasowe).

[2] Przykładowo, Esther MacCallum-Stewart i Justin Parsler proponują rozpatrywać gry historyczne jako „gry, które rozpoczynają się w wyraźnie określonym punkcie historii świata rzeczywistego i których to historia ma wyraźny wpływ na charakter rozgrywki." (Controversies: historicising the computer game, [w:] Proceedings of the 2007 DiGRA International Conference: Situated Play, red. D. Thomas, R. Apelman, Tokyo 2007, s. 204).

[3] A. Chapman, A. Foka, J. Westin, Introduction: what is historical game studies?, „Rethinking History” 2016, $\mathrm{nr} 21$ (3), s. 367.

[4] Przykładowo, Zach Whalen i Laurie N. Taylor we wstępie do tomu Playing the Past. History and Nostalgia in Video Games proponują rozpatrywać problematykę reprezentacji przeszłości przez pryzmat indywidualnych wspomnień (Nashville, 2008). Marina Hassapopoulou analizuje produkcje pokroju „Chernobyl VR Project” czy „08:46” (określanych mianem „docugames”), wykorzystując zagadnienia pamięci zbiorowej, narodowej traumy oraz turystyki śmierci (Playing with history: collective memory, national trauma, and dark tourism in virtual reality docugames, „New Review of Film and Television Studies” 2018, nr 16, s. 365-392). Dla Piotra Sitarskiego tematyka historyczna gier wideo stanowi podstawę do refleksji na temat ich historiozoficznego wydźwięku (Obroty kół historii. O historiozofii w grach komputerowych, [w:] Historia w kulturze współczesnej, red. P. Witek i inni, Lublin 2011, s. 53-6o). Z kolei Łukasz Czajka omawia historyczne gry wideo w kontekście ich edukacyjnego potencjału (Wielka Wojna jako temat gier wideo. Wyzwania dla edurozrywki $w$ Valiant Hearts $i$ Battlefield 1, „Homo Ludens” 2020, $\mathrm{nr}$ 1, s. 35-53). [5] M. Pakier, Pamięć historyczna, [w:] Modus memorandi. Leksykon kultury pamięci, red. M. Saryusz-Wolska, R. Traba, Warszawa 2014, s. 354-355 (wydanie elektroniczne). 
Powyższe rozpoznania uzupełniam o teorię wypracowaną przez Jörna Rüsena, wedle którego historia znaczeniowo obejmuje zarówno ponadepokową i ponadkulturową koncepcję „czasowo uporządkowanych dziejów”, jak i „interpretujące przedstawienie przeszłości w kulturowych ramach orientacyjnych teraźniejszości”[6]. To drugie, traktowane przez niemieckiego badacza jako wytwór pamięci historycznej, uobecnia przeszłość w formie narracji za pośrednictwem doświadczenia czasu (Zeiterfahrung), współtworzonego przez mechanizmy pamiętania (Erinnerung) i pamięci (Gedächtnis)[7]. Podsumowując, historia dla Jörna Rüsena jawi się jako „proces tworzenia sensu za pomocą doświadczenia czasu" [8] .

Mając na uwadze powyższe, proponuję traktować artykuł jako postulat włączania gier wideo w poczet nowych form medialnej interpretacji przeszłości. Podstawowym celem tekstu staje się wykazanie, za pomocą jakich środków Valiant Hearts: The Great War oraz My Memory of Us - dwa teksty kultury, nawiązujące kolejno do hekatomby I wojny światowej oraz zagłady Żydów - wykorzystują narracyjne oraz ludyczne struktury do tworzenia kommemoratywnych opowieści o przeszłości.

Aby realizacja powyższych założeń była możliwa, zamierzam w pierwszej kolejności wykazać zasadność zestawiania obu produkcji. Gra Valiant Hearts: The Great War, wydana w 2014 roku przez francuskie studio Ubisoft Montpellier, odnosi się bezpośrednio do wydarzeń historycznych, osadzając na tle I wojny światowej (frontu zachodniego lat 1914-1917) perypetie czwórki fikcyjnych postaci (Francuza Emile’a, Niemca Karla, Amerykanina Freddy'ego oraz Belgijki Anny). Z kolei My Memory of Us - produkcja polskiego studia Juggler Games z 2018 roku - na pierwszy plan wysuwa motyw wspomnień jako ramy kompozycyjnej utworu. Chociaż opowieść fikcyjnego księgarza-narratora spełnia założenia konwencji baśniowej, przedstawiane w niej losy dwójki przyjaciół - Chłopca i Dziewczynki, walczących o przeżycie w bezdusznym świecie opanowanym przez Złego Króla i jego armię robotów - bezpośrednio nawiązują do tragedii zagłady Żydów. Przyznają to sami twórcy, gdy identyfikują My Memory of Us jako „wesołą, steampunkową baśń splatającą się ze smutną i prawdziwą historią okupacji Polski w trakcie II wojny światowej”.

Istotna przesłanka, uprawomocniająca porównanie analizowanych produkcji, tkwi w ich podobieństwie gatunkowym, a konkretnie w mechanice rozgrywki stanowiącej klasyfikator genologiczny. Oba tytuły wpisują się w nurt platformowych gier 2D, jednocześnie sięgając po rozwiązania właściwe dla gier przygodowych (między innymi z uwagi na zagadki logiczne). Wykorzystują także poetykę komiksu - zwracają uwagę między innymi „dymki” jako forma komunikacji pomiędzy
Valiant Hearts i My Memory of Us w krajobrazie kultury historycznej
[6] Myślenie historyczne. Część I. Jörn Rüsen: Nadawanie historycznego sensu, red. R. Traba, H. Thünemann, Poznań 2015, s. 39.
[7] Ibidem, s. 36.

[8] Ibidem. 
postaciami. Potwierdzeniem treściowego i formalnego podobieństwa staje się recepcja krytyków opisujących My Memory of Us jako „polską odpowiedź” na dzieło Ubisoftu[9]. Tym samym, akceptując inspirujący wpływ Valiant Hearts na kształt późniejszej o trzy lata gry warszawskiego studia Juggler Games, możemy śledzić istniejące pomiędzy nimi zależności na wielu poziomach.

Bez wątpienia sposób kształtowania narracji w obu grach wynika w pewnym stopniu z lokalnych uwarunkowań kulturowych. Niemniej, uściślając ważne dla kultury historycznej pojęcie społeczności, postrzegam je przez pryzmat adresatów, jakim jest - zgodnie z prawami globalnego rynku gier wideo - ponadnarodowa społeczność graczy[10]. Taka strategia znajduje swoje potwierdzenie w fakcie, że pamięć o hekatombie Wielkiej Wojny oraz Zagładzie, chociaż modelowana lokalnymi uwarunkowaniami, ma na gruncie kultury masowej również wymiar uniwersalny[11].

Za reprezentanta globalnych tendencji służy między innymi kinematografia, z którą Valiant Hearts oraz My Memory of Us zdają się podejmować wyraźny dialog. Obie gry, z uwagi na antywojenny wydźwięk fabuły, stoją w kontrze do mainstreamowych gier wojennych, traktujących uśmiercanie przeciwników jako kluczowy element gameplaya. Interaktywne reprezentacje Wielkiej Wojny realizowane są głównie na obszarze trzech gatunków gier: strategii czasu rzeczywistego (na przykład Strategic Command: World War I, stawiających gracza na pozycji wszechwładnego generała przesuwającego na mapie żetony symbolizujące dywizje[12]), tak zwanych strzelanek pierwszoosobowych (między innymi Verdun, Battlefield 1 czy Beyond The Wire, gdzie doświadczenie wojny podporządkowane jest bezpośrednio obowiązkowi zabijania wrogów) oraz szeroko pojętych symulatorów (na przykład Rise of Flight: The First Great Air War, sprowadzającej konflikt

[9] Takie określenie zastosowała Sylwia Zimowska w recenzji serwisu Damagier.pl (<https://www.damagier.pl/gry-wideo/my-memory-of-us-recenzja/>, dostęp: 1.01.2021). Z kolei recenzent portalu Graczpospolita.pl zatytułował swój tekst "Gdy Valiant Hearts spotyka powstanie warszawskie" (<https://graczpospolita.pl/recenzja-my-memory-of-us/>, dostęp: 1.01.2021). Warto dodać, że jeszcze przed premierą prasa growa zapowiadała tytuł studia Juggler Games określeniem „godnego następcy” Valiant Hearts (<https://www.gry-online.pl/So22.asp?ID=12204>, dostęp: 1.01.2021).

[10] E. Shliakhovchuk, A. Muñoz García, Intercultural perspective on impact of video games on players: Insights from a systematic review of recent literature, „Educational Sciences: Theory \& Practice” 2020, nr 2o(1), s. 41-42.

[11] W szerszym ujęciu potwierdzają to Angela K. Smith i Sandra Barkhof, postrzegając doświad- czenia I i II wojny światowej (zwłaszcza Holocaustu) jako kluczowe w kształtowaniu badań nad pamięcią kulturową (War, Experience and Memory in Global Cultures Since 1914, red. A.K. Smith, S. Barkhof, New York 2018). Przykładem węższego ujęcia jest stanowisko Daniela Leviego, traktującego dwa symboliczne wydarzenia roku 1948 - utworzenie państwa Izrael oraz przyjęcie Powszechnej Deklaracji Praw Człowieka - jako przykład regionalnej i uniwersalnej formuły odnoszenia się do Holocaustu (D. Levi, Holocaust and Memory in the Global Age, Philadelphia 2005, s. 7-8). [12] Rozwinięciem tej reguły na polu innego gatunku jest gra Toy Soldiers (Signal Studios, 2010), przedstawiająca pierwszowojenne zmagania w konwencji Tower defense. Tutaj również zadaniem gracza - tym razem jako dowódcy ołowianych figurek na interaktywnej makiecie - jest uśmiercić jak najwięcej nacierających przeciwników. 
do wojny maszyn)[13]. Valiant Hearts wyróżnia się na tle powyższych tytułów: dekonstruuje „growy” dyskurs o wojnie i staje się bliższe tradycji pacyfistycznych arcydzieł kina wojennego, wyznaczanych przez takie dzieła jak Oskarżam! (reż. A. Gance, 1919), Na Zachodzie bez zmian (reż. L. Milesone, 1930; również pierwowzoru autorstwa Remarque’a), Towarzysze broni (reż. J. Renoir, 1937) czy Ścieżki chwały (reż. S. Kubrick, 1957)[14].

Podczas gdy liczba gier odnoszących się do II wojny światowej (realizowanej w wyżej wymienionych konwencjach gatunkowych) znacząco przekracza liczbę interaktywnych narracji o Wielkiej Wojnie, sama tematyka Zagłady - ze względów etycznych bądź prawnych - była przez deweloperów konsekwentnie pomijana[15]. Tym istotniejsza na polu kultury historycznej staje się koncepcja twórców My Memory of Us, aby wzorem Listy Schindlera (reż. S. Spielberg, 1993) za najważniejszy wyznacznik czarno-białego świata uczynić przypisaną do ofiar czerwień. To bezpośrednie nawiązanie do postaci Romy Ligockiej - filmowej „Dziewczynki w czerwonym płaszczyku”[16] - podkreśla nie tylko zasadność umieszczania My Memory of Us w ramach interakcji z innym medium, ale również nie pozostawia wątpliwości odnośnie do identyfikacji historycznych inspiracji. W szerszej perspektywie produkcja Juggler Games realizuje ważny nurt filmowej opowieści o Zagładzie, w której okrutna i irracjonalna rzeczywistość - niczym w Życie jest piękne (reż. R. Benigni, 1997) - ulega przetworzeniu przez pryzmat dziecięcej imaginacji.

Wybór tych konkretnych produkcji wynika nie tylko z faktu, że ich twórcy znajdują fabularne inspiracje w tragicznym wymiarze dwudziestowiecznej historii oraz - bezpośrednich i prawdopodobnych - inspiracjach kulturowych. Motywowany jest on również kom-

[13] Naturalnie niniejszy podział należy traktować jako poszukiwanie pewnej dominanty, akcentującej cechy omawianej gry. Przykładem pozycji wymykającej się nadanym ramom jest na przykład gra przygodowa 11-11: Memories Retold, opowiadająca o losach dwóch żołnierzy z przeciwnych stron konfliktu. Biorąc jednak pod uwagę, że jest dziełem twórcy Valiant Hearts, w jakimś aspekcie powiela wyjątkową, indywidualną postawę twórczą $(<\mathrm{https://}$ venturebeat.com/2018/04/25/valiant-hearts-creator-revisits-the-great-war-with-11-11-memories-retold/>, dostęp: 1.01.2021.

[14] Podczas gdy w niektórych przypadkach zasadne jest mówienie o duchowym pokrewieństwie pomiędzy tytułami (jak na przykład Oskarżam!, wyznającej wraz z Valiant Hearts sprzeciw wobec szaleństwa wojny), w innych nawiązania odnoszą się wręcz do konkretnych scen (na przykład scena rozstrzelania żołnierzy w Ścieżkach chwały oraz egzekucja Emile’a). [15] Na ten stan wskazuje między innymi Tomasz Michalik, omawiając w tekście z 2015 roku motyw Shoah na przykładzie trzech niszowych pozycji: Auschwitz Birkenau - puzzli internetowych na stronie Jig5aw, Sonderkommando Revolt - moda do gry Wolfenstein ${ }_{3} D$ oraz Learning Game - edukacyjnego projektu TheChildrenOfTheHolocaust.com (Pop-pamięć. Edukacja o Holocauście a gry komputerowe - od puzzli po „serious games”, „Acta Humana” 2014, nr 5, s. 132-133). Znaczącym wyjątkiem z przestrzeni mainstreamu, poza My Memory of Us, jest Wolfenstein: New Order (MachineGames, 2017). W tym wypadku również należy mówić o odwołaniu do motywu, gdyż sam obóz koncentracyjny Belica - nawet jeżeli powiela symbolikę oraz totalitarną funkcję rzeczywistych, nazistowskich obozów - stanowi wytwór fikcji rodem $\mathrm{z}$ historii alternatywnej.

[16] Warto przypomnieć, że zainspirowana sukcesem filmu, spisała po latach swoje wspomnienia w książce Dziewczynka w czerwonym płaszczyku (Kraków 2002). 
memoratywnym charakterem obu gier. Związek ten staje się widoczny już na poziomie nazewnictwa, gdy weźmiemy pod uwagę, że francuskojęzyczny tytuł Valiant Hearts brzmi Soldats inconnus: Mémoires de la Grande Guerre (tłum. Nieznani żołnierze. Wspomnienia Wielkiej Wojny). Jednocześnie kommemoratywny charakter gry Ubisoftu oraz jej źródłową perspektywę (fabułę opartą na listach żołnierzy) akcentowały materiały zapowiadające grę[17]. Również sam fakt ustalenia premiery na 24 czerwca 2014 roku (a więc niemal setną rocznicę zamachu na arcyksięcia Franciszka Ferdynanda w Sarajewie) wpisywał produkcję w cykl kilkuletnich uroczystych obchodów polityczno-narodowych[18]. Intencjonalny wymiar takiej strategii, nadającej procesowi deweloperskiemu znamiona swoistej „pracy pamięci”, znajduje potwierdzenie zarówno w działaniach wewnątrz zespołu (na przykład nastawionych na potęgowanie doświadczenia kontaktu z przeszłością poprzez analizę źródeł historycznych[19]), jak i poprzez zaproszenie społeczności do interakcji w ramach akcji Valiant Stories Memorabilia Contest. Przedsięwzięcie, zachęcające do dzielenia się przez graczy pamiątkami rodzinnymi z czasów Wielkiej Wojny oraz przesyłania związanych z nimi wspomnień, gwarantowało zwycięzcom umieszczenie przedmiotu w rozgrywce, a co za tym idzie - jego „unieśmiertelnienie”[20].

Chociaż nierealistyczna konwencja graficzna My Memory of Us sprawia wrażenie, że odwołania historyczne odgrywają dla Juggler Games drugorzędną rolę, w praktyce przeczy temu umieszczenie w obrębie menu głównego sekcji Wspomnienia. Zawarta w niej wiadomość dla gracza - oparta na formule bezpośredniego zwrotu do adresata - nie tylko informuje o rzeczywistych inspiracjach oraz obecności w fabule historycznych postaci, ale również odsłania istotną intencję, jaką jest przeciwdziałanie zapomnieniu o tragedii i bohaterach tamtych czasów. Co więcej, tutaj również kluczowy staje się gracz, bez którego zaangażowania w rozgrywkę poznanie historii nie jest możliwe. „Chcielibyśmy piszą twórcy - aby ich dokonania i postawy przetrwały dzięki Twojej podróży w tej grze. Warto ich odkryć i warto pamiętać”.

Powyższe spostrzeżenia potwierdzają, że refleksja o przeszłości może być istotą narracji gry. Odwołując się do podziału wypracowanego przez Jörna Rüsena (jednocześnie mając na uwadze umowny charakter zaproponowanej typolologii, której był świadomy sam badacz[21]), można stwierdzić, że Valiant Hearts oraz My Memory of Us odnoszą się do trzech sfer tworzących istotę kultury historycznej: politycznej (są elementem obchodów rocznicowych), estetycznej (stanowią przy-

[17] Ubisoft, Valiant Hearts E3 Trailer [US], <https:// youtu.be/MP8q5F6dFqQ>, dostęp: 1.01.2021.

[18] E. Wanda George, M. Das, Remembering World War I: memory influences and impact on intentions to visit war heritage sites, "Journal of Tourism \& Hospitality" 2017, vol. 6, nr 2, s. 1, <https://www. longdom.org/open-access/remembering-world-war-i-memory-influences-and-impact-on-intentionsto- -visit-war-heritage-sites-2167-0269-1000273.pdf>, dostęp: 1.01.2021.

[19] Ubisoft, Valiant Hearts. Developer Diary 1: Art \& Emotion [US], <https://youtu.be/XQSD-JZruIw>, dostęp: 1.01.2021.

[20] Ubisoft, Valiant Stories Memorabilia Contest, <https://youtu.be/zu9RgTwR6UU>, dostęp: 1.01.2021. [21] Myślenie historyczne..., s. 39. 
kład artystycznej interpretacji przeszłości) oraz kognitywnej (pełnią funkcję źródła wiedzy o historii). W ten sposób tworzy się cały system treściowych i formalnych zależności skupionych wokół przeszłości jako kulturowego punktu odniesienia.

Szczególnie charakterystyczna w tym zakresie kulturowego porozumienia $z$ odbiorcą staje się warstwa wizualna (rysunkowa animacja 2D) oraz powiązana z nią poetyka komiksu. Przykładowo, „dymki” ze znakami piktograficznymi konkretyzują nieartykułowane dialogi lub sygnalizują kondycję postaci. Z kolei dzielony w pionie ekran dynamizuje akcję poprzez dodanie równoległej sceny, zwraca uwagę na zbliżające się zagrożenie lub poszukiwane przez gracza przedmioty[22]. Tego typu zabiegi pozwalają na obrazowe przedstawienie niektórych mechanik (na przykład Emile używający chochli jako łopaty do przekopywania ziemi). Należy przyjąć, że taka stylistyka nie tylko uniwersalizuje przekaz (domyślnymi odbiorcami My Memory of Us oraz Valiant Hearts są również dzieci), ale paradoksalnie pogłębia refleksję odnośnie do komiksu jako „labiryntu pamięci” w mariażu słowa i obrazu[23]. Symboliczny w tym wymiarze okazuje się przykład czarno-białej stylistyki My Memory of Us. Na tle monochromatycznej przestrzeni wyróżniają się czerwone elementy, za którymi podąża uwaga gracza.

Kulturowa gra $\mathrm{z}$ odbiorcą toczy się także na polu interpretacji poszczególnych elementów ikonosfery, wykazującej potencjał tworzenia historycznych sensów[24]. Najwyraźniej dzieje się tak w Valiant Hearts, gdzie dbałość o szczegóły - umundurowania, proporców czy elementów architektury - wynikała ze starannego wzorowania się na źródłach z epoki[25]. W przypadku My Memory of Us wizualność determinowana jest przez kontrast. Szeroko pojęta stylistyka steampunku (reprezentowana przez elementy industrialne, w tym monstrualne maszyny oraz robotycznych agresorów) łączy się z wizualnymi odniesieniami do kultury materialnej okresu II wojny światowej oraz Zagłady[26]. Część z nich ma wymiar scenograficznych „wskazówek” (na przykład elementy ubioru i umundurowania, tramwaje, plakaty piętnujące „naznaczonych”), pozostałe tworzą swoją symbolikę w obrębie całych scen (na przykład getto otoczone drutem kolczastym). W tym układzie dodatkowymi łącznikami pomiędzy sferą faktu a fikcji stają się te elementy scenografii (na przykład obrazy z wizerunkami królów oraz

\section{Strategie kulturowego porozumienia z odbiorcą}

[22] Rozwinięcie tego tematu znajduje się w części poświęconej mechanice zbieractwa.

[23] Więcej na ten temat pisze Grażyna Gajewska, wykorzystująca motyw labiryntu w omawianiu komiksów opartych na doświadczeniu wojny, między innymi Hiroszima 45 oraz Maus (za: Stowo - obrazpamięć w labiryntach komiksu, „Biblioteka” 2008, nr 12 (21), s. 105-106).

[24] Myślenie historyczne..., s. 59.
[25] Ubisoft, Valiant Hearts. Developer Diary $1 . .$. [26] Co istotne, konwencja steampunkowa, będąca w istocie wariacją odnośnie do czasów wiktoriańskich oraz okresu rewolucji przemysłowej, wpisuje się w kategorię historii alternatywnych (patrz: I. Ramos, R.F. BURTON Revisited: Alternate history, steampunk and the neo-victorian imagination, „Open Cultural Studies" 2017, nr 1, s. 591-592). 
Złego Króla), których zmienna konfiguracja (strącanie i zawieszanie) oddaje tożsamościowy aspekt oporu wobec totalitaryzmu.

Strategia porozumienia $\mathrm{z}$ graczem realizuje się również w kontekście czasu akcji, ułatwiającego identyfikację konwencji opowiadania. Chociaż w Valiant Hearts pojawiają się grywalne retrospekcje (na przykład przybliżające okoliczności znalezienia się postaci na froncie), nawet one nie wybiegają poza okres I wojny światowej. Przykładem jest prolog, wprowadzający pierwszych bohaterów (Emile’a oraz jego niemieckiego zięcia Karla, odpowiednio wcielonego do armii francuskiej i deportowanego do Rzeszy), który uzupełniony został historycznym komentarzem odnoszącym się do początków konfliktu. Wszechwiedzący narrator, zawężający opowieść do konkretnej przestrzeni (mapy Europy Zachodniej), przedstawia genezę Wielkiej Wojny w ciągu przyczynowo-skutkowym: od zabójstwa arcyksięcia Franciszka Ferdynanda do ogłoszenia przez Francję powszechnej mobilizacji 1 sierpnia 1914 roku. Od tego momentu gra prowadzi uczestnika przez fabułę uwarunkowaną osią czasu (dokładna datacja), historycznymi przestrzeniami (między innymi miejsca kluczowych bitew) oraz perypetiami fikcyjnych postaci. W tym sensie uprawione wydaje się stwierdzenie, że strategia upamiętniania przeszłości w Valiant Hearts nawiązuje do założeń powieści historycznej, rozpiętej pomiędzy poszanowaniem faktów a kreowaniem angażującej fikcji[27].

Biorąc pod uwagę, że My Memory of Us podlega steampunkowej konwencji, kwestią drugorzędną staje się, czy opowieść starego księgarza - traktującego o perypetiach dwójki dzieci, próbujących przetrwać w świecie rządzonym przez Złego Króla - plasuje się bliżej założeniom bajki czy baśni[28]. Niemniej strategia narracyjna Juggler Games nakazuje wskazać na specyfikę relacji pomiędzy fantastyczną otoczką a jej historycznymi inspiracjami na gruncie trzech płaszczyzn czasowych: teraźniejszości (narracji księgarza z off-u, nadającej fabule szkatułkową formę), przeszłości uhistorycznionej (relacji ze spotkania dziewczynki i księgarza) oraz przeszłości skonwencjonalizowanej (opowieści o wojennych doświadczeniach swojej młodości). Chociaż w każdej z nich zrezygnowano - zgodnie z założeniami baśni - z bezpośredniego precyzowania czasu i miejsca akcji, interpretacyjnym kluczem pozostaje teraźniejszość. Za sprawą kompozycji ramowej nie tylko uświadamia istotę upływającego czasu, ale staje się bodźcem do refleksji odnośnie do doświadczania historii przez pryzmat cudzej, subiektywnej pamięci. Tym samym wizualną konwencjonalizację wspomnień o ludobójstwie

[27]. Problem ten w kontekście gatunkowości nurtu rozważa szczegółowo między innymi K. Bartoszyński, Konwencje gatunkowe powieści historycznej, „Pamiętnik Literacki" 1984, vol. LXXV, z. 2, s. 3-7.

[28] Piotr Liszka, uznając baśń za bardziej rozbudowaną formę bajki, używa argumentacji, która bliska jest założeniom niniejszego tekstu. Wedle badacza „Baśń jest utworem literackim złożonym i bogatym w możliwości interpretacyjne. Do jej odczytania potrzebne jest myślenie abstrakcyjne, odróżniające zapis symboliczny od zawartej w nim prawdy, fikcję od realiów". (cyt. za: P. Liszka, Znaczenie formy literackiej zwanej baśnia w teologii dla ukazywania istotnych wartości humanistycznych, „Perspectiva” 2015, nr 2, s. 57). 
można rozpatrywać dwojako: jako dostosowanie treści do wrażliwości odbiorcy lub próbę oswajania traumy z przeszłości.

Zasadność powyższej interpretacji potwierdza narratorska charakterystyka Dziewczynki-słuchaczki jako miłośniczki fabuł o „potworach, robotach i bitwach”. W tym znaczeniu gatunkowość wpisuje się w edukacyjną koncepcję przyswajania treści historycznych za pośrednictwem ulubionych konwencji i motywów, a co więcej - pozwala pogłębić refleksję o problematykę pedagogicznego znaczenia baśni[29]. Znamienna w tym kontekście jest metaforyzacja okupacji niemieckiej, stająca się w świecie wspomnień księgarza (ofiary systemu) oraz wyobraźni dziecka (postaci, z którą najpełniej identyfikuje się gracz?) krainą baśniowego Zła. Sugestywna kolorystyka (między innymi wszechobecna szarość, intensyfikująca się ku czerni wraz z narastaniem powagi kolejnych scen i kontrastująca z czerwienią bohaterów), posępna architektura (na przykład strzeliste kominy, nasuwające skojarzenie z mrocznymi zamczyskami) oraz sprowadzenie okupantów do roli automatów kreuje sugestywny wizerunek bezdusznego, nazistowskiego totalitaryzmu, a jednocześnie parasol ochronny dla dziecięcej wrażliwości oraz cierpienia ofiary[30].

Wśród rozmaitych form gameplayowej aktywności szczególnie ważną funkcję pełnią tak zwane collectibles - rozmieszczone w świecie gry elementy do zbierania, funkcjonujące pod nazwami Faktów historycznych, Przedmiotów historycznych (Valiant Hearts) oraz Wspomnień (My Memory of Us). Chociaż ich zdobywanie nie jest wymagane do ukończenia rozgrywki, w praktyce - poza realizowaniem uniwersalnych mechanizmów, nagradzających gracza za umiejętności lub zaangażowanie - pozwalają omówić popularyzatorskie i upamiętniające funkcje gier.

Pierwszą napotkaną w Valiant Hearts aktywnością zbieracką są tak zwane Fakty historyczne: zbiór ponad pięćdziesięciu plansz, stworzonych we współpracy z historykami Mission Centenaire 14-18 oraz producentami serialu dokumentalnego Apocalypse World War I[31]. Plansze, uaktywniające się wraz z początkiem każdego rozdziału jako opcjonalna lektura, zawierają omówienie w kluczu popularyzatorskim

[29] Chociaż klasyczne spostrzeżenia Bruno Bettelheima odnoszą się głównie do wyzwań związanych $z$ procesem socjalizacji oraz radzenia sobie przez dziecko z wyzwaniami rzeczywistości, postrzeganie baśni jako zachęty do walki z trudnościami jako nieodłącznymi elementami życia uzasadnia odwoływanie do strategii przetwarzania przeszłości na gruncie pracy pamięci (cyt. za: B. Bettelheim, Cudowne i pożyteczne. O znaczeniu i wartościach baśni, t. 1, Warszawa 1985, s. 46).

[30] Poszukującemu analogii w innych tekstach kultury nasuwa się przykład Maus (gdzie pod postacią

\section{Narracja historyczna jako element rozgrywki}

relacji pomiędzy zwierzętami - częstymi bohaterami baśni - autor zawarł cała groteskę i metaforyczność doświadczenia Zagłady) lub Wrońca Jacka Dukaja (przetwarzającego przez pryzmat dziecięcej wyobraźni wydarzenia stanu wojennego).

[31] Instytucja, ustanowiona $\mathrm{w} 2012$ roku z ramienia rządu francuskiego w celu popularyzacji wiedzy o Wielkiej Wojnie oraz przygotowania narodu na obchody setnej rocznicy jej zakończenia (patrz: <https:// www.centenaire.org/fr >, dostęp: 1.01.2021; Ubisoft, Valiant Hearts Developer Diary 3: History, <https:// youtu.be/PlbO7oXuZcA $>$, dostęp: 1.01.2021). 
wybranych zagadnień z okresu Wielkiej Wojny. Ukierunkowana na faktografię narracja oferuje graczowi pogłębienie odbioru fabuły poprzez wgląd w fotografie $\mathrm{z}$ epoki oraz omówienie przełomowych starć (między innymi Bitwa pod Neuve-Chapelle), postępu technologicznego (Czołg Mark 1), ewolucji strategii prowadzenia wojny (Okopy) czy formacji i grup w niej uczestniczących (Pamięć o marokańskiej dywizji). Jednocześnie umożliwia nakreślenie maksymalnie szerokiego obrazu frontu zachodniego w okresie 1914-1918 z perspektywy różnych dziedzin nauki historycznej: wojskowej (Miotacze ognia), społecznej (Sanitariuszki), gospodarczej (Szyny kolejowe), prawa (Żandarmeria wojskowa), sztuki (Katedra Notre-Dame w Reims), idei (Zdobycie flagi), kultury materialnej (Odznaczenia wojenne), a także antropologii historycznej (Wieś okresu wojny) oraz mikrohistorii (Listy).

Kolejne dwie aktywności związane z poszukiwaniem przez użytkownika ukrytych w grze elementów możemy rozpatrywać w ramach jednej grupy. Chociaż wirtualne „artefakty” funkcjonują pod pozornie nieprzystawalnymi pojęciami Przedmiotów historycznych (bliskich definicji źródła historycznego[32]) oraz Wspomnień (przynależnych do problematyki pamięci), w praktyce łączy je tożsama mechanika (oparta na poszukiwaniu przez gracza-postać ukrytych elementów), estetyka przedstawienia (przedmioty i zdjęcia są wizualizowane zgodnie ze stylistyką świata przedstawionego), a także potraktowanie samego wysiłku eksploracji jako drogi do zgłębienia historycznych aspektów fabuły.

Analogicznie do Faktów historycznych, odkrywane w Valiant Hearts przedmioty przedstawiane są za pomocą reprezentacji graficznej (rysunku wiernie odwzorowującego oryginał) oraz popularnonaukowego opisu. Niemniej, dzięki silnemu utożsamieniu z kulturą materialną swoich czasów, stanowią przykład poszerzenia faktografii z zakresu historii powszechnej o szereg kontekstów związanych z przejawami mikrohistorii oraz historii życia codziennego: świadectw przemian społecznych (Kombinezon), ewolucji obyczajowości (Krzyż), kulturowych aspektów żołnierskiego wyposażenia (Nóż kukri), rozwoju technicznego (Maszynka do golenia) czy życia medialnego (Dyplom „Wojennej matki”). Przykładowo, znalezisko Szmatka nasaczona moczem informuje gracza o pierwszych sposobach radzenia sobie z gazem bojowym, Puszka sardynek porusza zagadnienie dziennej racji żywnościowej oraz roli przesyłanych z domu produktów, zaś Grzebień na wszy nakreśla kontekst tragicznych warunków sanitarnych w okopach. Dodatkowo opisy towarzyszące monetom wzbogacone zostały o przeliczniki pozwalające porównać wartość ówczesnych i dzisiejszych pieniędzy.

Z kolei Wspomnienia, umieszczone w My Memory of Us pod postacią zagubionych fotografii, tworzą dosłowną "galerię pamięci”

[32] Cytując klasyczną definicję Gerarda Labudy: „Źródłem historycznym nazwiemy wszystkie pozostałości psychofizyczne i społeczne, które, będąc wytworem pracy ludzkiej, a zarazem uczestnicząc w rozwoju życia społeczeństwa, nabierają przez to zdolności odbijania tego rozwoju" (cyt. za: G. Labuda, Próba nowej systematyki i nowej interpretacji źródet historycznych, „Studia Źródłoznawcze. Commentationes", t. I, Warszawa 1957, s. 22). 
o wymiarze biograficznym i faktograficznym. Jest to galeria wizualnie skonwencjonalizowana (oprawione w ramki wizerunki postaci należy uznać jedynie za symboliczne), która przekazuje encyklopedyczną wiedzę o postaciach (Elżbieta Zawacka, Władysław Szpilman, Józef Unrug, Henryk Sławik, Janusz Korczak, Irena Sendler, Marek Edelman, Witold Pilecki, Jan Karski, Mordechai Anielewicz), zbiorowościach (Polski żotnierz, Dzieci w getcie) oraz wydarzeniach (Powstanie warszawskie) z okresu niemieckiej okupacji ziem polskich. Chociaż wybór niektórych elementów w zestawieniu $\mathrm{z}$ fabułą utworu sprawia wrażenie mniej przemyślanego niż w grze Ubisoftu (dlaczego zdecydowano się opisać powstanie warszawskie zamiast kluczowego dla perypetii bohaterów powstania w getcie?), to również na polu narracji historycznej podtrzymuje kommemoratywne funkcje rozgrywki.

Powyższe spostrzeżenia zdają się potwierdzać, że autorska narracja o przeszłości w medium gry obejmuje także mechaniki fakultatywne. Odkrywane i kolekcjonowane przez gracza przedmioty stanowią łącznik z epoką, dają poczucie jej namacalności oraz budują wyjątkowość obrazowanego wycinka czasu. Większość z nich ma charakter symboliczny i uruchamia konteksty kulturowe (na przykład nieśmiertelniki), inne - współtworzą faktograficzny obraz ówczesnej codzienności. W tym sensie mają one niezaprzeczalną wartość edukacyjną i popularyzatorską, nadającą narracji wiarygodności oraz utrzymują merytoryczną relację z przeszłą rzeczywistością. Ponadto akcentują rolę źródła historycznego (przedmiotów i opisów z epoki) oraz historiografii (narracji popularnonaukowej) jako kluczowych elementów poznania przeszłości zarówno na gruncie nauki historycznej, jak i w sferze pamięci.

Uwypuklenie znaczenia zbiorowości w Valiant Hearts i My Memory of Us odbywa się na dwóch poziomach: z jednej strony użytkownik steruje kilkoma postaciami, a z drugiej - twórcy starannie obrazują nie tylko bohaterów grywalnych, ale i drugoplanowych. Nawigowanie w przestrzeni za pośrednictwem różnych protagonistów ma zarówno istotne znaczenie fabularne (choćby pozwala ukazać to samo wydarzenie z odmiennych perspektyw, na przykład bitwę pod Neuve Chapelle), jak i gameplayowe, gdyż kooperacja pomiędzy bohaterami (rozwiązywanie zagadek logicznych, korzystanie z unikalnych umiejętności itp.) warunkuje postęp w grze.

Aspektem podkreślającym totalny charakter obu wojen stanowi przedstawienie perypetii postaci na tle cierpienia innych podmiotów: cywilów (na przykład mieszkańców getta), żołnierzy (na przykład rannych i umierających pod Marną) oraz zwierząt (psa zaplątanego w druty kolczaste). W Valiant Hearts tłem stają się lokacje postrzegane jako symboliczne reprezentacje okresu Wielkiej Wojny: elementy infrastruktury wojskowej (koszary, lazaret, obóz jeniecki, więzienie wojskowe), pola bitew (okopy, transzeje, ziemia niczyja), a także skupiska ludności cywilnej (między innymi bombardowane Reims). Analogicz-

Pomiędzy perspektywą zbiorową a indywidualną 
nie, imaginacyjna otoczka My Memory of Us jeszcze silniej akcentuje tragedię bohatera zbiorowego dzięki interpretacji przestrzeni przez pryzmat historii: uwięzienia w getcie (otoczonym drutem kolczastym i posterunkami strażniczymi), wywózek do obozów (fałszywa jadłodajnia - obietnica polepszenia życia - zmieniająca się w wagon pociągu) czy powstańczej walki o godność. W obu przypadkach uwarunkowana historycznie przestrzeń wirtualna staje się niejako odpowiednikiem rzeczywistych miejsc pamięci o zbiorowym cierpieniu[33].

Fabuła Valiant Hearts oraz My Memory of Us pozwala rozpatrywać ich narrację również w kontekście perspektywy jednostki. Interpretacyjny trop w przypadku produkcji Ubisoftu stanowią listy wojenne - kolekcjonowane przez graczy jako zapis autentycznych źródeł[34]. Napisane przez szeregowych żołnierzy kilkunastu narodowości (od Niemców po Tunezyjczyków), oddają one nie tylko skalę konfliktu, ale - paradoksalnie - tworzą wspólnotę ludzi połączonych podstawowym pragnieniem: zakończenia wojny i powrotu do normalności. Obecnie, odgrywając rolę głosu z epoki, przynajmniej częściowo spełniają założenia świadectwa („relacjonowania minionych zdarzeń przez ich uczestnika - widza, bohatera czy ofiary - w perspektywie indywidualnej pamięci"[35]). Tym samym umożliwiają graczowi lekturę tekstu w kategoriach immersyjnego „dotknięcia” historii, a zarazem uwiarygadniają grę Ubisoftu jako opowieść inspirowaną realiami I wojny światowej.

Skoncentrowanie twórców My Memory of Us na przejawach pamięci (między innymi narracja prowadzona jest za pośrednictwem wspomnień ocalałego z ludobójstwa) sprawia, że zasadne staje się rozbudowanie definicji świadectwa o pojęcie świadka historii: „naocznego świadka, który - nierzadko jako jedyny ocalały - umknął katastrofie i składa o niej relację dla innych i dla potomności[36]. Chociaż postać księgarza stanowi wymysł czystej fikcji, w rzeczywistości symbolizuje figurę jednego z czołowych reprezentantów tej grupy - naocznego świadka Zagłady, dającego dowód żywej pamięci o traumatycznej przeszłości. Co więcej, nawet autorefleksyjne przyznawanie się narratora do łagodzenia lub wyolbrzymiania niektórych zdarzeń oddaje zastrzeżenia nastawionych pozytywistycznie historyków do wiarygodności świadka historii, to jednocześnie wpisuje się w Assmanowską wyrozumiałość dla „świadka moralnego”[37]. Ostatecznie to dzięki relacji naocznych obserwatorów, przekazujących swoją opowieść Chłopcu, stary księgarz

[33] Taką tezę pozwala wysunąć na przykład Tomasz Burdzik, rozpatrujący przestrzeń jako płaszczyznę konstruowania tożsamości zbiorowej oraz powiązanego z nią poczucia wyjątkowości (Przestrzeń jako składnik tożsamości $w$ świecie globalizacji, „Kultura Historia - Globalizacja” 2012, nr 11, s. 24-26).

[34] TSA, Guillaume Cerda on The Letters and Emotions That Inspired Valiant Hearts, <https://www. thesixthaxis.com/2014/05/15/guillaume-cerda-on-the- -letters-and-emotions-that-inspired-valiant-hearts/>, dostęp: 1.01.2021.

[35] M. Marszałek, Świadectwo, [w:] Modus memorandi. Leksykon kultury pamięci, red. M. Saryusz-Wolska, R. Traba, Warszawa 2014, s. 851 (wydanie elektroniczne).

[36] Ibidem, s. 853.

[37] „Nawet jeśli od czasu do czasu szczegóły tych wspomnień mijają się z faktami, autentyczność 
mógł opowiedzieć swojej słuchaczce między innymi o ostatniej drodze „doktora Janusza” i jego wychowanków (inspirowanej działalnością Korczaka w getcie oraz pochodzie na Umschlagplatz), a także pomocy okazywanej uciekinierom ze strony „siostry Ireny” (wzorowanej na Irenie Sendlerowej).

Również charakterystyczną dla gry czerwień - piętno nakładane w czarno-białym świecie przez okupantów - należy rozpatrywać nie tylko jako symbol samego ludobójstwa, ale również znak rozpoznawczy świadków historii, naznaczonych pamięcią o okrucieństwie swoich czasów. Chociaż barwa zanika w odniesieniu do postaci Dziewczynki, która po ucieczce z getta otrzymuje nową tożsamość[38] - Chłopiec, zgodnie z własnym wyborem, pozostaje z nią przez większość życia. Dopiero jako dorosły, po przekazaniu swojej opowieści oraz nabyciu wiedzy o losie przyjaciółki, w symbolicznym zakończeniu pozbywa się towarzyszącego mu piętna. Otwartą interpretacją pozostaje, czy akt ten wyznacza kolejną odsłonę „sztafety pamięci” (przekazywanie wiedzy o przeszłości graczowi), czy bliższy jest finalnemu przepracowaniu traumy.

Punktem wyjścia dla omówienia narracji w odniesieniu do perspektywy ofiar jest motyw wojny jako początku końca dawnego świata. W przypadku My Memory of Us zapowiedzi nadchodzącego konfliktu między innymi wiszące na murach plakaty propagandowe, montowanie stanowisk ckm-ów na rogach ulic - poprzez czytelne nawiązania historyczne stają się zauważalne dla gracza prędzej niż dla nieświadomych bohaterów. Tym bardziej więc wojna nadchodzi - tak jak śmierć świeżo poślubionej żony Freddy'ego podczas bombardowania - nagle i niespodziewanie, wpisując się w koncepcję Rüsenowskiej „przypadkowości doświadczenia" [39]. W Valiant Hearts wydarzenia „wielkiej historii” przyjazd funkcjonariuszy z nakazem deportacji do Niemiec - zastają Karla podczas pracy w polu. Z kolei zapowiedź narratora My Memory of Us o nadchodzącej tragedii towarzyszy Dziewczynce podczas zabawy na huśtawce („To były wspaniałe czasy. Wydawało się, że nic nie może ich zepsuć. Nie mieliśmy pojęcia, co czyha tuż za rogiem”).

Totalna skala nadchodzącego zagrożenia akcentowana jest również w gameplayu, w ramach którego zarzucono klasyczną dla gier platformowych mechanikę kilku „żyć”. Tutaj „życie” jest tylko jedno, a w przypadku porażki użytkownik zmuszony jest wczytać ostatni zapis

\section{Rozgrywka jako płaszczyzna} utożsamienia $\mathrm{z}$ ofiarą doświadczeń biograficznych i ich dozgonne, często traumatyczne reperkusje zapewniają świadkom moralnym niekwestionowany autorytet, odkąd istnieje społeczna gotowość recepcji”. A. Assmann, Między historia a pamięcia. Antologia, Warszawa 2013, s. 204. [38] Takie ujęcie obrazuje między innymi problem rozpięcia pomiędzy polską a żydowską tożsamością wśród „sierot Holocaustu”. J. Cukras-Stelągowska, $\dot{Z} y d z i$ - tożsamość wobec zmiany, [w:] Różni razem.
Młodzi polscy naukowcy o Żydach, red. J. Żyndul, Warszawa 2008, s. 275.

[39] Dla Jörna Rüsena koncepcja ma wymiar podwójny - jako „wielkie wydarzenie polityczne, które całościowo podają w wątpliwość określone tradycje historyczne i wzorce interpretacji”, jak i „małe katastrofy w życiu codziennym" (cyt. za Myślenie historyczne..., s. 445). 
rozgrywki. Ponadto losy bohaterów uwarunkowane są rozwojem fabuły, a nie umiejętnościami gracza. Kontrast jest tym większy, że bohaterowie wyrzekają się stosowania przemocy. Chociaż za sprawą swoich unikalnych możliwości (na przykład rzucania przedmiotami na odległość, skradania się, szybkiego biegania) oraz potencjału intelektualnego (skutecznością rozwiązywanych przez gracza zagadek logicznych) nie są całkowicie bezbronni, to mimo wszystko nie mają szans wobec potencjału militarnego wroga (stanowisk ckm-ów, patroli z psami, bombardowań itp.), z którym konfrontują się gołymi pięściami lub uzbrojeni w improwizowaną broń (na przykład chochlę). Niewątpliwie takie ujęcie wynika z potrzeby dostosowania narracji do młodych odbiorców, jednak wiąże się również $\mathrm{z}$ odrzuceniem estetyki turpizmu lub narracji, w których antywojenny wydźwięk idzie $\mathrm{w}$ parze $\mathrm{z}$ nadaktywnością postaci $\mathrm{w}$ hekatombie (zob. first-person shooters, wojenne filmy akcji).

Dysproporcja sił wiąże się również z doświadczeniem opresji, po które sięga wrogi system. Znamiennym przykładem jest scena $\mathrm{My} M e-$ mory of Us, w której podczas selekcji mieszkańców dzieci zostają skierowane na wagę. Gdy szala urządzenia opada ku ziemi, Dziewczynka zostaje podświetlona czerwienią, a następnie wciągnięta do wnętrza olbrzymiej maszyny i osadzona na fabrycznej taśmie. Gracz, obserwując przebieg wydarzeń z punktu widzenia zaniepokojonego Chłopca, zagląda do wnętrza mechanizmu. Chociaż proces „zaczerwieniania” ubrania Dziewczynki pozbawiony jest elementu przemocy, kolejne etapy - na przykład ładowanie przez żołnierzy (stylizowanych na oficerów SS) pojemników z farbą - wywołują skojarzenia związane z ludobójczym wymiarem Zagłady. Totalny charakter opresji podkreśla zarówno masowość represji, jak i niezbywalność koloru-piętna. Scena spuentowana zostaje wymownym ujęciem Złego Króla, który, dzierżąc w ręku wagę wypełnioną ludźmi, odważa ich niczym towar. Czerwień przybiera barwę symbolicznej, ofiarnej krwi[40]. Co istotne, „zaczerwienienie” nie tylko determinuje zmiany w świecie przedstawionym (na przykład pojawienie się plakatów piętnujących „czerwonych” czy symbolicznego zamknięcia nieinteraktywnych elementów przestrzeni, na przykład tramwajów), ale również w gameplayu (dostęp do niektórych lokacji będzie posiadał wyłącznie Chłopiec). Jednocześnie, dokonuje się wizualne zróżnicowanie ofiar systemu; niektórzy, jak na przykład Janusz Korczak, przedstawiani są jako częściowo zaczerwienieni, co sugeruje ich „połowiczne” pochodzenie lub szczególne przywiązanie do sprawy piętnowanych.

[40] Jednocześnie totalitarny mechanizm, polegający na piętnowaniu wybranych grup, niesie w świecie gry rozczarowanie społeczeństwem, które w części ze strachu lub ukrytych animozji - zaczęło myśleć w narzucony przez okupanta sposób, w konsekwencji nabierając robotycznych cech. Niniejsza symbolika poza przedstawieniem uniwersalnych mechanizmów wykluczenia - stanowi czytelny punkt odniesienia względem polskiego antysemityzmu, potwierdzany narracją księgarza: „Przez Złego Króla wszystko zmieniło się na gorsze. Ludzie gapili się na czerwonych, zaczęli ich inaczej traktować. Na początku burczeli pod nosem, a czasami mówili rzeczy pełne nienawiści. $Z$ czerwonych nie ma żadnego pożytku. Teraz można było to powiedzieć głośno. Skąd się wzięły te myśli? Nagle można było je usłyszeć wszędzie. Patrzyłem na moją przyjaciółkę i nie różniła się wcale od tej, którą była przez cały czas”. 
Istotną kategorię kształtującą stosunek postaci - a pośrednio gracza - do świata przedstawionego stanowi niezgoda na panujące zło. W kontekście wymowy Valiant Hearts wiąże się to z odrzuceniem przez postaci nie tylko przemocy, ale również napędzających je czynników propagandowych. Chociaż brak intencji patriotycznych (nie wspominając o szowinistycznych, typowych dla nastrojów początków wojny) może być uznany za element ahistoryczny, w praktyce stanowi jeszcze silniejsze podkreślenie bezsensownego charakteru wojny. Okazywanie męstwa służy więc dwóm podstawowym celom: walce o przeżycie (aby powrócić do normalności) oraz ratowaniu życia innych ludzi (aby nie zatracić się w okrucieństwie wojny). W tym znaczeniu odrzucenie przez Emile’a przyznanych mu orderów czy opatrywanie przez Annę rannych Niemców ma rangę oporu wobec obłudy systemu.

Analogicznie, w My Memory of Us doświadczenie oporu także objawia się jako solidarność naznaczonych i wobec naznaczających. Wykonywane przez gracza misje, których celem jest niesienie pomocy mieszkańcom getta (zdobywanie towarów, szmuglowanie dzieci, akty „małego sabotażu”), wpisują się w kluczowy zabieg przywracania godności ofiarom. Na polu fikcji pragnienie to przedstawione zostaje jako triumf dziecięcej zmyślności nad Złym Królem. Na polu nawiązań historycznych taką funkcję spełnia narracja o heroicznym zrywie naznaczonych wobec okupantów (powstania w getcie warszawskim). Tłem dla wspomnień Księgarza, streszczającego zasłyszane informacje o tragedii zrywu, stają się przetworzone archiwalia (budynki niszczone miotaczami ognia) oraz kulturowe symbole oporu (mężczyzna stający z koktajlem Mołotowa naprzeciwko czołgu; mechaniczna stopa szykująca się do zmiażdżenia drobnych figurek).

Wymienione powyżej motywy oraz wątki łączą się w finalnym doświadczeniu, jakim jest poczucie straty. Jej najskrajniejszym przejawem jest naturalnie sama śmierć, mająca wymiar jednostkowy (na przykład Dziadek Dziewczynki, Żona Freddy'ego), jak i masowy (wywóz mieszkańców getta upiornym, podniebnym pociągiem, zagłada całych oddziałów na polach Wielkiej Wojny). Biorąc jednak pod uwagę, że sugerowanym przez twórców kluczem interpretacyjnym jest doświadczenie pamięci, to właśnie ono, jako świadomość straty nieodwracalnej, ma konstytuujący wymiar. W przypadku My Memory of Us przejmująca pustka towarzyszy graczom między innymi podczas przejścia przez opustoszałe getto, a następnie wspinania się po olbrzymim stosie porzuconych walizek. Przeglądanie rzeczy ofiar w poszukiwaniu czerwonego misia - podkreślone w warstwie dźwiękowej szlochaniem oraz lamentacyjną tonacją muzyki klezmerskiej - pogłębia uderzające (zwłaszcza z perspektywy młodego gracza) poczucie żałoby po ludziach, których już nie ma.

Analogiczne mechanizmy pogłębiania immersji pojawiają się w finale Valiant Hearts, gdy to sam gracz zmuszony jest poprowadzić Emiléa - oskarżonego o przyczynienie się do śmierci oficera - przed francuski pluton egzekucyjny. W ramach interaktywnej sceny, gdy skuta 
łańcuchami postać imaginuje przed sobą kolejne postacie przyjaciól, uczestnik rozgrywki zostaje zmuszony do nieodwołanego pożegnania się z bliskim sobie bohaterem.

Ostatecznie jednak uświadamianie historycznego wymiaru straty (poległych na wojnie, zamordowanych w czasie Zagłady) prowadzi do finalnej konkluzji, jaką stanowi wartość płynąca z trwania pamięci. „Dedykuję ją wszystkim, którzy musieli odejść od tych, których kochali, i którzy przetrwali wystarczająco długo, by zobaczyć ich ponownie" konkluduje stary Księgarz. Podobną wartość podziela narrator Valiant Hearts, mówiąc nad grobem Emile’a: „Chociaż ich ciała dawno temu zamieniły się w proch, pamięć o ich poświęceniu wciąż żyje. Musimy starać się pielęgnować te wspomnienia i nigdy nie zapominać...” W tym znaczeniu świadome obcowanie z Valiant Hearts oraz My Memory of Us nakłada na gracza ostateczne zadanie, za którym kryje się kluczowa istota rozgrywki: podtrzymywania trwania w formie żywej pamięci o doświadczeniach ludzi z przeszłości.

W stronę nowych narracji o przeszłości
B I B L I O G R A F I A
Zarówno Valiant Hearts, jak i My Memory of Us stanowią przykłady tekstów, w których przeszłość rozpatrywana jest w oparciu o doświadczenie ofiary - jednostki oraz zbiorowości wtłoczonej w tryby historii. Jednocześnie, specyficzne dla medium gier mechanizmy immersji w dużo większym stopniu pozwalają ukierunkować empatię oraz akt współodczuwania jako jeden ze sposobów upamiętniania traumatycznych wydarzeń przeszłości, a także współtworzenia dyskursu o ich teraźniejszym wymiarze.

Chociaż obie gry jako przejawy twórczości artystycznej podlegają silnemu skonwencjonalizowaniu, bliskiemu założeniom powieści historycznej oraz opowiadania fantastycznego, to zarazem zastosowane w nich strategie nawiązują do historycznych sposobów poznawania przeszłości: analizy źródeł historycznych, poznawaniu faktografii oraz gromadzeniu relacji w postaci wspomnień świadków historii. Jednocześnie gry wideo proponują całkiem nowe możliwości wprowadzania treści edukacyjnych (popularnonaukowych) - a nawet historiograficznych - warunkowanych interaktywnością. W tym znaczeniu stanowią obiecującą próbę połączenia perspektywy historii oraz pamięci zbiorowej w ramach jednego medium. Niewykluczone więc, że gry wideo w przyszłości okażą się tym rodzajem tekstów, które w ramach szeroko pojętej kultury historycznej współtworzyć będą nowe formy narracji o przeszłości.

Assmann A., Między historia a pamięcią. Antologia, Warszawa 2013

Bartoszyński K., Konwencje gatunkowe powieści historycznej, „Pamiętnik Literacki” 1984, vol. LXXV, z. 2, s. 3-44

Bettelheim B., Cudowne i pożyteczne. O znaczeniu $i$ wartościach baśni, t. 1, Warszawa 1985 
Burdzik T., Przestrzeń jako składnik tożsamości w świecie globalizacji, „Kultura Historia - Globalizacja” 2012, nr 11, s. 13-27

Chapman A., Foka A., Westin J., Introduction: what is historical game studies?, „Rethinking History” 2016, nr 21(3), s. 358-371

Cukras-Stelągowska J., Żydzi - tożsamość wobec zmiany, [w:] Różni razem. Młodzi polscy naukowcy o Żydach, red. J. Żyndul, Warszawa 2008, s. 268-281

Czajka Ł., Wielka Wojna jako temat gier wideo. Wyzwania dla edurozrywki w Valiant Hearts i Battlefield 1, „Homo Ludens” 2020, nr 1, s. 35-53

Gajewska G., Słowo - obraz - pamięć w labiryntach komiksu, „Biblioteka” 2008, nr 12(21), s. 101-115

Hassapopoulou M., Playing with history: collective memory, national trauma, and dark tourism in virtual reality docugames, „New Review of Film and Television Studies" 2018, nr 16, s. 365-392

Labuda G., Próba nowej systematyki i nowej interpretacji źródeł historycznych, „Studia Źródłoznawcze. Commentationes", t. I, Warszawa 1957, s. 3-52

Levi D., Holocaust and Memory in The Global Age, Philadelphia 2005

Liszka P., Znaczenie formy literackiej zwanej baśnia w teologii dla ukazywania istotnych wartości humanistycznych, „Perspectiva” 2015, nr 2, s. 55-67

MacCallum-Stewart E., Parsler J., Controversies: Historicising the Computer Game, [w:] Proceedings of the 2007 DiGRA International Conference: Situated Play, red. D. Thomas, R. Appelman, Tokyo 2007, s. 203-210.

Marszałek M., Świadectwo, [w:] Modus memorandi. Leksykon kultury pamięci, red. M. Saryusz-Wolska, R. Traba, Warszawa 2014, s. 851-861

Michalik T., Pop-pamięć. Edukacja o Holocauście a gry komputerowe - od puzzli po „serious games”, „Acta Humana” 2014, nr 5, s. 127-138

Muriel D., Crawford G., Video Games as Culture. Considering the Role and Importance of Video Games in Contemporary Society, London - New York 2018

Myślenie historyczne. Część I. Jörn Rüsen: Nadawanie historycznego sensu, red. R. Traba, H. Thünemann, Poznań 2015

Pakier M., Pamięć historyczna, [w:] Modus memorandi. Leksykon kultury pamięci, red. M. Saryusz-Wolska, R. Traba, Warszawa 2014, s. 354-361

Playing the Past. History and Nostalgia in Video Games, red. Z. Whalen, L.N. Taylor, Nashville 2008

Ramos I., R.F. BURTON Revisited: alternate history, steampunk and the neo-victorian imagination, „Open Cultural Studies” 2017, nr 1, s. 591-603

Shliakhovchuk E., Muñoz García A., Intercultural perspective on impact of video games on players: insights from a systematic review of recent literature, „Educational Sciences: Theory \& Practice" 2020, nr 20(1), s. 40-58

Sitarski P., Obroty kót historii. O historiozofii w grach komputerowych, [w:] Historia w kulturze współczesnej, red. P. Witek i inni, Lublin 2011, s. 53-60

Wanda George E., Das M., Remembering World War I: Memory influences and impact on intentions to visit war heritage sites, „Journal of Tourism \& Hospitality" 2017, vol. 6, nr 2, <https://www.longdom.org/open-access/remembering-world-war-i-memory-influences-and-impact-on-intentionsto-visit-war-heritage-sites-2167-0269-1000273.pdf >, dostęp: 1.01.2021

War, Experience and Memory in Global Cultures Since 1914, red. A.K. Smith, S. Barkhof, New York 2018

11-11: Memories Retold (Digixart Entertainment Studios i Aardman Animation, 2018)

PR Z Y W O $~ A N E$

GRY W I DE O

Battlefield 1 (EA DICE, 2016) 
Beyond The Wire (Redstone Interactive, 2020)

My Memory of Us (Juggler Games, 2018)

Rise Of Flight: The First Great Air War (777 Studios, 2009)

Strategic Command: World War I (Fury Software, 2011)

Toy Soldiers (Signal Studios, 2010)

Valiant Hearts: The Great War (Ubisoft Montpellier, 2014)

Verdun (M2H i Blackmill Games, 2015)

Wolfenstein: New Order (MachineGames, 2017)

PRZYWOŁANE Ź R Ó D Ł A

IN T E R N E T O W E
Mirowski J., Widzieliśmy polskie My Memory of Us - Valiant Hearts ma godnego następce, <https://www.gry-online.pl/S022.asp?ID=12204>, dostęp: 1.01.2021

Mission Centenaire 14-18 - oficjalna strona projektu, <https://www.centenaire. org/fr>, dostęp: 1.01.2021

Mucharzewski M., Gdy Valiant Hearts spotyka powstanie warszawskie - recenzja My Memory of Us, <https://graczpospolita.pl/recenzja-my-memory-of-us>, dostęp: 1.01.2021

Takahashi D., Valiant Hearts creator revisits The Great War with 11-11: Memories Retold, <https://venturebeat.com/2018/04/25/valiant-hearts-creator-revisits-the-great-war-with-11-11-memories-retold/>, dostęp: 1.01.2021

TSA, Guillaume Cerda On The Letters And Emotions That Inspired Valiant Hearts, $<$ https://www.thesixthaxis.com/2014/05/15/guillaume-cerda-on-the-letters-and-emotions-that-inspired-valiant-hearts/>, dostęp: 1.01.2021

Ubisoft, Valiant Hearts Developer Diary 3: History, <https://youtu.be/PlbO70XuZcA>, dostęp: 1.01.2021

Ubisoft, Valiant Hearts E3 Trailer [US], <https://youtu.be/MP8q5F6dFqQ>, dostęp: 1.01 .2021

Ubisoft, Valiant Hearts. Developer Diary 1: Art \& Emotion [US], <https://youtu.be/ XQSD-JZruIw>, dostęp: 1.01.2021

Zimowska S., My Memory of Us - recenzja, <https://www.damagier.pl/gry-wideo/ my-memory-of-us-recenzja/>, dostęp: 1.01.2021 